\title{
DOUBLE BLIND TRIAL OF DEXTROMORAMIDE, METHADONE AND PETHIDINE IN THE TREATMENT OF SEVERE PAIN
}

\author{
*S. G. Flavell MatTs, M.B., Ch.B., M.R.C.P.(Ed.) $\quad$ C. H. J. Swan, M.B., Ch.B. \\ The Royal Hospital, Wolverhampton \\ B. A. Wharton, M.B., Ch.B., D.C.H., \\ The Middlesex Hospital, London, W.I
}

SEVERE pain is a recurrent problem in the treatment of many diseases, and its relief is an important part of the management of the illness. Many analgesics are in existence but few are really effective in therapy. Most people are still agreed that the drugs of the opiate group are probably the most effective for pain relief. Unfortunately, the use of these drugs is marred by the occurrence of unpleasant and sometimes dangerous side-effects, particularly respiratory depression, nausea, vomiting and addiction. It is extremely difficult to design a good clinical trial to discriminate between drugs used in the relief of pain. Uncontrolled trials are of no value because they depend too much on the subjective impressions of the patient and observers. Controlled trials are difficult to organise because of their time-consuming nature, difficulties with the D.D.A. regulations and the problems of assessing degrees and duration of pain relief. Many of these difficulties have been stressed in excellent reviews of the subject by Swerdlow and Murray (1962), and Swerdlow, Murray and Daw (1963). In view of the importance of obtaining accurate information on this subject, we felt that an investigation employing a double blind technique would be the best method of avoiding false clinical bias and erroneous impressions. It was felt that a comparison of three commonly used oral analgesics would determine, by this method, any difference between them. Pethidine is very widely used and was therefore one of the drugs chosen. Methadone, which is another well-established and widely-used analgesic, was the second drug included in the trial. For the third drug we chose the relatively new analgesic dextromoramide (Palfium), which originated in Belgium and had been described by Janssen and Jageneau (1957, 1958). The use of dextromoramide has been described in this country by Cope and Jones (1959), Gavin (1960), Kagan (r96r) and Matts (r962); and it has been found to be an effective and safe analgesic in clinical practice.

*In receipt of a Research Grant from the Birmingham Regional Hospital Board.
TABLE I-Dextromoramide $10 \mathrm{mg}$.

\begin{tabular}{|c|c|c|c|}
\hline \multicolumn{2}{|l|}{ Diagnosis } & $\begin{array}{l}\text { Length } \\
\text { of } \\
\text { effects } \\
\text { (hours) }\end{array}$ & Side-effects \\
\hline Raynaud's disease . . & $\ldots$ & 3 & Nil \\
\hline Diabetic gangrene .. & . & 3 & Nil \\
\hline Pleurisy $\quad \ldots$. & . & 4 & Nil \\
\hline Carcinomatosis & . & 3 & Nil \\
\hline \multicolumn{2}{|c|}{ Subarachnoid hæmorrhage } & 4 & Nil \\
\hline Pleurisy $\quad \ldots \quad \ldots$ & .. & 6 & Dizziness \\
\hline Coronary thrombosis & .. & 6 & Nausea \\
\hline Scleroderma , $\ldots$ & . & 5 & Nil \\
\hline \multicolumn{2}{|c|}{ Subarachnoid hæmorrhage } & 12 & Nil \\
\hline Carcinomatosis $\quad \ldots$ & . & $\begin{array}{l}\text { No } \\
\text { effects }\end{array}$ & Nausea \\
\hline \multicolumn{2}{|c|}{ Severe rheumatoid arthritis } & 5 & Nil \\
\hline Diabetic gangrene & $\cdots$ & 4 & Nil \\
\hline Angina & $\cdots$ & 4 & Nil \\
\hline Cervical spondylosis & $\cdots$ & 6 & Nil \\
\hline Coronary thrombosis & $\cdots$ & 6 & Nil \\
\hline Pleurisy $\quad: \ldots, \quad \ldots$ & $\cdots$ & 4 & Nil \\
\hline \multicolumn{2}{|c|}{ Subarachnoid hæmorrhage } & 3 & Nil \\
\hline Cerebral tumour . . & $\cdots$ & 3 & Dizziness \\
\hline Severe migraine,$\ldots$ & $\cdots$ & 4 & Nil \\
\hline \multirow{2}{*}{\multicolumn{2}{|c|}{ Subarachnoid hæmorrhage }} & 6 & Nil \\
\hline & & 12 & Nil \\
\hline Gangrene $\quad \cdots$. & $\cdots$ & 4 & Nil \\
\hline Carcinomatosis $\quad \because$ & $\cdots$ & $\mathbf{I}$ & Nil \\
\hline \multicolumn{2}{|l|}{ Coronary thrombosis } & 2 & $\begin{array}{l}\text { Faintness and } \\
\text { dizziness }\end{array}$ \\
\hline Pleurisy & . & 4 & Nil \\
\hline Lumbar spondylosis & $\cdots$ & 4 & Nil \\
\hline Carcinomatosis & $\cdots$ & 3 & Nil \\
\hline Gangrene .. & $\cdots$ & 2 & Nil \\
\hline Pleurisy $\quad \therefore$ & $\cdots$ & $\mathbf{r}$ & Nil \\
\hline \multicolumn{2}{|c|}{ Subarachnoid hæmorrhage } & 8 & Nil \\
\hline
\end{tabular}

Summary

30 patients; 29 obtained relief of from I to 12 hours, 5 patients developed side-effects-no respiratory depression.

\section{Method}

Three lots of tablets were prepared externally completely identical. Each tablet contained either $5 \mathrm{mg}$. of 
TABLE 2-Methadone 10 $\mathrm{mg}$.

\begin{tabular}{|c|c|c|c|c|}
\hline \multicolumn{3}{|c|}{ Diagnosis } & $\begin{array}{l}\text { Length } \\
\text { of } \\
\text { effects } \\
\text { (hours) }\end{array}$ & Side-effects \\
\hline Pleurisy & . & & $\mathbf{I}$ & Nil \\
\hline Severe angina & .. & $\cdots$ & 3 & Nil \\
\hline Cerebral tumour & $\ldots$ & $\ldots$ & 4 & $\begin{array}{l}\text { Sweating and } \\
\text { drop in B.P. }\end{array}$ \\
\hline Diabetic gangrene & 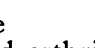 & & I & Vomiting \\
\hline \multirow{3}{*}{\multicolumn{3}{|c|}{$\begin{array}{l}\text { Severe rheumatoid arthritis } \\
\text { Subarachnoid hæmorrhage } \\
\text { Coronary thrombosis }\end{array}$}} & 8 & Nil \\
\hline & & & 4 & Nil \\
\hline & & & 3 & Dizziness \\
\hline Pleurisy $\quad .$. & .. & $\theta$ & 6 & Dizziness \\
\hline Carcinomatosis & . & . & 8 & $\begin{array}{l}\text { Respiratory } \\
\text { depression }\end{array}$ \\
\hline & 12 & Nil \\
\hline Carcinomatosis & the & . & 3 & $\begin{array}{l}\text { Respiratory } \\
\text { depression }\end{array}$ \\
\hline \multirow{3}{*}{\multicolumn{3}{|c|}{$\begin{array}{l}\text { Subarachnoid hæmorrhage } \\
\text { Acute peptic ulcer } \\
\text { Arteriosclerotic gangrene ... }\end{array}$}} & 3 & Nil \\
\hline & & & 4 & Nil \\
\hline & & & No & Nil \\
\hline \multicolumn{3}{|l|}{ Severe Raynaud's } & & \\
\hline phenomena & . & . & 2 & Sweating \\
\hline Severe migraine & .. & . & 3 & Nil \\
\hline Pleurisy & & $\ldots$ & 4 & Nil \\
\hline Coronary thrombo & osis & 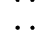 & 5 & Vomiting \\
\hline Cerebral tumour & & .. & 3 & Nil \\
\hline Coronary thrombo & & & 4 & Dizziness \\
\hline Severe rheumatoid & $\mathrm{d}$ arthri & & 3 & Nil \\
\hline Pleurisy $\quad .$. & & . & 4 & Nil \\
\hline Carcinoma of thyro & roid & $\ldots$ & 5 & Nil \\
\hline Subarachnoid hæm & morrhag & & 4 & Nil \\
\hline Severe angina & & & 3 & Nil \\
\hline Diabetic gangrene & & & 4 & Nil \\
\hline Sciatica & & & 3 & Nil \\
\hline \multicolumn{3}{|c|}{ Osteoporotic vertebral } & & \\
\hline collapse.. & .. & $\cdots$ & 3 & Nil \\
\hline Angina & .. & .. & I & Nil \\
\hline Carcinomatosis & .. & $\ldots$ & 4 & Nil \\
\hline
\end{tabular}

\section{Summary}

30 patients; 29 obtained relief of pain from I to 12 hours, 9 experienced side-effects, two of which were respiratory depression.

dextromoramide, $5 \mathrm{mg}$. of methadone or $50 \mathrm{mg}$. of pethidine. The dosage range of dextromoramide is from 5 to $10 \mathrm{mg}$., of methadone 5 to $10 \mathrm{mg}$., and of pethidine 50 to $100 \mathrm{mg}$. In order to obtain a standard effect it was decided to give the upper range of dosage and therefore all patients would be treated with either Io mg. of dextromoramide, ro mg. of methadone or 100 mg. of pethidine, this dose being contained in two tablets. Thus all the patients were prescribed two tablets of one of these analgesics, which were identified by letters A, B or C. Only the pharmacist knew which was which of these and this knowledge was not revealed until after the entire trial was completed. Thus neither doctors, nurses nor patients were aware of the contents of the tablets at the time of the trial and assessment. The patients were those admitted to a general medical ward and were suffering with a variety of conditions which had produced severe pain. They were assessed by the authors and were adjudged as being in need of a powerful analgesic because of this severe pain. Having thus been included in the trial they were prescribed, by a method of random selection,
TABle 3-Pethidine roo mg.

\begin{tabular}{|c|c|c|c|c|}
\hline \multicolumn{3}{|c|}{ Diagnosis } & $\begin{array}{l}\text { Length } \\
\text { of } \\
\text { effects } \\
\text { (hours) }\end{array}$ & Side-effects $\frac{\stackrel{2}{c}}{c}$ \\
\hline \multirow{2}{*}{\multicolumn{2}{|c|}{ Coronary thrombosis }} & . & 3 & Nil \\
\hline & & & I & Dizziness등 \\
\hline \multirow{2}{*}{\multicolumn{3}{|c|}{ Diabetic gangrene }} & 4 & Dizziness \\
\hline & & & 6 & Sweating \\
\hline \multicolumn{3}{|c|}{$\begin{array}{lll}\text { Pleurisy } & \cdots & \end{array}$} & 3 & $\begin{array}{l}\text { Respiratoro } \\
\text { depression }\end{array}$ \\
\hline \multirow[t]{2}{*}{$\begin{array}{lll}\text { Sciatica } & \ldots & \text {. }\end{array}$} & .. & $\cdots$ & $\begin{array}{l}\text { No } \\
\text { effects }\end{array}$ & Nil क \\
\hline \multirow{3}{*}{\multicolumn{2}{|c|}{$\begin{array}{l}\text { Carcinomatosis } \\
\text { Paget's disease } \\
\text { Angina } \\
\text { Coronary thrombosi }\end{array}$}} & $\ldots$ & 2 & Nil \\
\hline & & $\cdots$ & 8 & Nil $\overrightarrow{\vec{\omega}}$ \\
\hline & & & 3 & Vomiting \\
\hline \multirow{2}{*}{\multicolumn{3}{|c|}{$\begin{array}{l}\text { Coronary thrombosis } \\
\text { Arteriosclerotic gangrene .. }\end{array}$}} & 5 & Nil 흘 \\
\hline & & $\begin{array}{l}\text { Subarachnoid hæmorrhage } \\
\text { Severe migraine }\end{array}$ & 4 & Nil \\
\hline Severe migraine & . & & $\begin{array}{l}\text { No } \\
\text { effects }\end{array}$ & Nil \\
\hline \multirow{2}{*}{$\begin{array}{l}\text { Severe migraine } \\
\text { Osteo-arthritis }\end{array}$} & . & $\cdots$ & 3 & Nil 龸 \\
\hline & .. & $\cdots$ & 6 & $\begin{array}{l}\text { Respirator: } \\
\text { depressiop }\end{array}$ \\
\hline \multicolumn{2}{|l|}{ Pleur } & & 7 & Nil \\
\hline \multirow{2}{*}{\multicolumn{3}{|c|}{$\begin{array}{l}\text { Diabetic gangrene } \\
\text { Severe rheumatoid arthritis }\end{array}$}} & 3 & Nil \\
\hline & & & 4 & Nil \\
\hline \multicolumn{2}{|c|}{$\begin{array}{l}\text { Acute peptic ulcer } \\
\text { Coronary thrombosis }\end{array}$} & . & 5 & Sweating $\overline{7}$ \\
\hline \multicolumn{2}{|c|}{$\begin{array}{l}\text { Coronary thrombosis } \\
\text { Angina }\end{array}$} & .. & 9 & Nil \\
\hline Angina & . & & $\begin{array}{l}\text { No } \\
\text { effects }\end{array}$ & Nil \\
\hline \multicolumn{3}{|c|}{ Subarachnoid hæmorrhage } & No & $\mathrm{Nil} \mathrm{O}^{\circ}$ \\
\hline Carcinomatosis & .. & . & $\begin{array}{l}\text { errects } \\
8\end{array}$ & $\begin{array}{c}\text { Collapse } \frac{O}{w i f g} \\
\text { sweating }\end{array}$ \\
\hline \multicolumn{2}{|c|}{$\begin{array}{l}\text { Pleurisy } \ldots \\
\text { Cervical spondylosis }\end{array}$} & .. & 4 & Nikêㅁ \\
\hline \multirow{2}{*}{\multicolumn{2}{|c|}{$\begin{array}{l}\text { Cervical spondylosis } \\
\text { Coronary thrombosis } \\
\text { Cerebral tumour ... }\end{array}$}} & $\cdots$ & 5 & $\mathrm{Nil} F$ \\
\hline & & $\because$ & 3 & $\begin{array}{l}\text { Nil } \\
\text { Nil }\end{array}$ \\
\hline \multicolumn{2}{|c|}{ 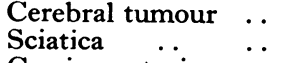 } & $\therefore$ & 4 & Nil \\
\hline Carcinomatosis & 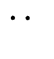 & & $\begin{array}{l}\text { No } \\
\text { effects }\end{array}$ & Nil \\
\hline \multicolumn{2}{|l|}{ Axillary abscess } & $\ldots$ & 3 & Nil \\
\hline
\end{tabular}

30 patients; 25 obtained relief of pain from 1 hours, 8 developed side-effects, 2 of which were tespiratory depression.

either analgesic A, B or C. The results of therapy recorded from the observations of the medical s? nursing staff and the statements of the patients themselves as regards their feeling of relief from pain, the duration of this relief and the 'occurrence of any sigeeffects. An analysis of the results can be seen in Tabjes I, 2, 3 and 4 .

\section{Results}

As can be seen from the tables, differences betwieen the three groups were not great. A total of 90 pationts in all were included in the trial. In the dextromoramude group (30 patients) 29 patients obtained relief from pain and five patients developed side-effects, none of these being respiratory depression. In the methadifne group ( 30 patients) 29 patients obtained relief of $p$ 羿 $n$, 9 patients experienced side-effects, two of these being respiratory depression. In the pethidine group to patients) 25 patients obtained relief of pain and enht patients developed side-effects, two of which vore 
TABle 4

\begin{tabular}{|c|c|c|}
\hline Drug & & $\begin{array}{l}\text { Average duration of } \\
\text { pain relief (hours) }\end{array}$ \\
\hline $\begin{array}{l}\text { Dextromoramide ro mg. } \\
\text { Methadone ro mg. } \\
\text { Pethidine 100 } \mathrm{mg} .\end{array}$ & $\begin{array}{l}\cdots \\
\cdots \\
\cdots\end{array}$ & $\begin{array}{l}4.4 \\
3.8 \\
3.6\end{array}$ \\
\hline
\end{tabular}

respiratory depression. The best average duration of relief of pain was dextromoramide with 4.4 hours, methadone came second with 3.8 hours and pethidine last with 3.6 hours.

\section{Discussion}

The use of oral analgesics is considerably larger than those given by injection because of their ease of administration. It is therefore important to know the relative efficacy and dangers of analgesics in common use. The trial results appear to confirm the clinical impression held by many people that there is little difference between the more powerful oral analgesics. However, dextromoramide does show marginal advantages over the other two agents. The average duration of pain relief was slightly higher, the incidence of side-effects lower and there were no cases in which respiratory depression was a feature. These findings may be of particular value outside hospital practice where patients will take analgesics as and when necessary for their pain in their own homes. In these circumstances the increased duration of pain relief with dextromoramide is particularly valuable and the reduction in the number of dangerous side-effects a feature which adds greatly to the safety, because the patients will not normally be under continuous surveillance, as they would be from the nursing staff in a hospital. The fact that there are so many oral analgesics makes it even more important that one should choose the best available drug for the type of pain experienced by the patient, taking into account the presence of various disease entities which may make other analgesics undesirable for various reasons (i.e. respiratory depression undesirable in pneumonia or pleurisy etc.).

Although it is said that 'man made aspirin, morphine came from heaven', a patient suffering severe side-effects from morphine may well feel that the direction of origin of morphine may have been reversed! For this reason alternatives to morphine should always be considered, and of these the three employed in this trial are acceptable, with the evidence pointing to a marginal advantage to dextromoramide, particularly in cardiorespiratory or cerebral conditions.

\section{Summary}

A double-blind trial of dextromoramide, pethidine and methadone in severe pain was carried out. The results are not strikingly different, but marginal advantages in favour of dextromoramide do emerge, particularly for home use or in cardiorespiratory or cerebral cases.

\section{REFERENCES}

Cope, E., and Jones, P. O. (1959): Relief of Post-operative Pain, Brit. med. F., i, 2 I I.

Gavin, R. (1960): The Alleviation of Intractable Pain, Ibid., ii, I917.

Janssen, P. A. J., and Jageneau, A. H. (1957): A New Series of Potent Analgesics, F. Pharm. Pharmacol., 9, 38r.

(1958): A New Series of Potent Analgesics, Ibid, ro, 14.

Kagan, G. (1961): Dextromoramide: a New Analgesic, Med. Press, 245, I 54.

MatTs, S. G. F. (1962): Dextromoramide Analgesia in the Acute General Medical Patient, Practitioner, 188, 524.

Swerdlow, M., and Murray, A. (1962): 'Some Difficulties in the Assessment of Post-operative Pain', European Congress of Anæsthiology (Vienna), 1962.

- - and Daw, R. H. (1963): A Study of Post-operative Pain, Acta ancesth. scand., 7, I. 